\title{
Comparison of detachment procedures for direct counts of bacteria associated with sediment particles, plant litter and epiphytic biofilms
}

\author{
Nanna Buesing*, Mark O. Gessner \\ Department of Limnology, EAWAG/ETH, Limnological Research Center, 6047 Kastanienbaum, Switzerland
}

\begin{abstract}
Efficient detachment of bacterial cells is crucial for assessing bacterial abundance, biomass and community composition in natural and technical systems (e.g. sewage plants) by a wide range of analytical methods. There is no agreement on which procedure gives the best results with which type of substratum. We tested the effect of 4 detachment instruments on the release of bacteria associated with leaf litter, sediment and epiphytic biofilms from a natural aquatic system. Treatment with most instruments increased bacterial counts and biovolumes significantly compared to simple vortexing (by 2.7 to $7 \times$ ). However, both the numbers and biovolume of released bacterial cells varied significantly between detachment devices. With leaf litter and epiphytic biofilms, an ultrasonic probe treatment released 10 and 4 times more bacterial cells than the most inefficient instrument. A stomacher-type blender gave the best results for sediment samples, releasing 3 times higher numbers of bacteria than the least efficient instrument. Neither the detachment instrument nor the treatment time affected the composition of bacterial morphotypes. These results indicate that the choice of the appropriate detachment device depends critically on the type of substratum examined, when the absolute abundance or biomass of bacteria is to be determined. In qualitative analyses of bacterial community structure the chosen device appears to be less important.
\end{abstract}

KEY WORDS: Epifluorescence microscopy $\cdot$ Bacterial direct counts $\cdot$ Method $\cdot$ Sediment $\cdot$ Leaf litter · Epiphyton $\cdot$ Biofilm $\cdot$ Wetland

Resale or republication not permitted without written consent of the publisher

\section{INTRODUCTION}

Accurate estimates of bacterial abundance, biomass and community structure are a critical prerequisite for assessing the roles of bacteria in food webs and biogeochemical cycles and understanding their population dynamics in natural systems. A variety of approaches have been proposed for studying bacteria in natural environments. These include direct counts by means of epifluorescence or electron microscopy (Fry 1988, Kepner \& Pratt 1994, Fischer \& Velimirov 2000), solid-phase cytometry (Lemarchand et al. 2001), flow cytometry (DeLeo \& Baveye 1996, Lebaron et al. 1998, Servais et al. 1999), scanning confocal laser microscopy (Lawrence et al. 1997), and examination of

*E-mail: nanna.buesing@eawag.ch purified DNA and RNA for bacterial community analyses (Holben 1997, Frischer et al. 2000). Most of these methods are relatively straightforward when freeliving bacteria are examined in pelagic environments; however, when particle-associated bacteria are investigated, a quantitative detachment of cells from their substratum is preferable in nearly all cases (Fry 1988).

A fundamental difficulty in separating bacteria efficiently from their substratum lies in the conflict between using procedures harsh enough to achieve near-complete detachment and the concomitant risk of cell disruption. Consequently, conditions need to be carefully chosen such that detachment efficiencies are maximized while cell damage is kept to a minimum. A variety of procedures have been proposed to this end for a range of systems in which particle-associated bacteria are important (e.g. Ellery \& Schleyer 1984, 
Velji \& Albright 1986, Epstein \& Rossèl 1995, Griebler et al. 2001). Methods that have been considered effective include sonication with an ultrasonic bath (Ellery \& Schleyer 1984, Weyers \& Suberkropp 1996) or probe (Epstein \& Rossèl 1995, Tso \& Taghon 1997), and mechanical treatment with tissue grinders such as Ultra-Turrax and Polytron homogenizers (Suberkropp \& Klug 1976, Meyer-Reil et al. 1978, Montagna 1982, Baldy et al. 1995) or Stomacher-type laboratory blenders (Donegan et al. 1991, Baldy et al. unpubl.). Studies that have compared different procedures have led to partially conflicting results. Part of these discrepancies may be due to different procedures adopted in different laboratories, even though the same basic approach and instruments may have been used (Epstein \& Rossèl 1995). The 4 above-mentioned detachment methods have not been systematically compared.

Contrasting results may also be caused by differences in the physical characteristics of the substratum to which bacteria are attached. In vegetated aquatic systems such as salt and freshwater marshes, seagrass beds or submerged macrophyte meadows in lakes, at least 3 different types of particle-attached bacteria can be distinguished: sediment bacteria, a large part of which form biofilms on mineral surfaces; bacteria associated with deposited organic matter; and bacteria in epiphytic biofilms colonizing submerged plant surfaces. Bacterial cells on mineral particles may be more easily damaged as a result of shear stress than bacteria associated with organic substrata. Conversely, cells partially located within an organic matrix such as a decaying leaf may require particularly harsh conditions to insure effective removal. Thus, a general comparison of detachment devices and procedures needs to take possible effects of the substratum into account.

Our objectives in the present investigation were to (1) test the effectiveness of 4 different procedures in detaching bacteria from 3 benthic substrata commonly found in vegetated systems, (2) determine the optimal treatment times for releasing bacterial cells, and (3) test whether the proportions of different bacterial morphotypes change as a function of treatment time and instrument.

\section{MATERIALS AND METHODS}

Sample collection and preparation. Three types of environmental samples were compared. Sediment, submerged leaf litter and epiphyton on submerged sections of reed culms were collected from the littoral zone of a Swiss lake dominated by the common reed Phragmites australis (Cav.) Trin. ex Steud. Surface sediment with a low organic matter content $(6.2 \%$ of dry weight) was sampled, placed in a polyethylene bag and returned to the laboratory in a cool box. The dominant particle size fraction was silt, as determined with a SediGraph 5100 Particle Size Analysis System (Micrometrics), which measures the gravity-induced settling rates of particles (Webb \& Orr 1997). Submerged decaying leaves of $P$. australis were collected by hand, placed in plastic boxes, covered with lake water and stored in a cool box until processed. For epiphyton samples, submerged culms of $P$. australis were clipped off just above the sediment surface. Culm sections were trimmed and inserted in combusted glass tubes $(20 \mathrm{~cm}$ length) containing lake water, which were closed with Teflon-lined screw caps and returned to the laboratory. All samples were processed immediately upon arrival at the laboratory.

The sediment was thoroughly mixed with a spatula before a total of sixteen $0.5 \mathrm{ml}$ subsamples of the slurry were removed using a $1 \mathrm{ml}$ plastic syringe with the Luer end cut off. The slurries were transferred to $20 \mathrm{ml}$ glass scintillation vials, $10 \mathrm{ml}$ of a $2 \%$ formalin solution (buffered with $0.1 \%$ sodium pyrophosphate) was added, and the vials were stored at $4^{\circ} \mathrm{C}$ in the dark. To prepare litter samples, a total of 24 discs were cut from each of 6 leaves with a cork borer (6.7 mm diameter) and allocated to $20 \mathrm{ml}$ glass vials. This resulted in 4 replicate sets of 6 discs, each cut from a different leaf. Ten milliliters of buffered formalin was added. Additional leaf discs were cut to determine sample dry mass and organic matter content. Epiphytic biofilm was carefully scraped off from sections of Phragmites australis culms with a scalpel and collected in graduated $50 \mathrm{ml}$ centrifuge tubes. The volume was made up to $50 \mathrm{ml}$ before samples were vortexed. A $5 \mathrm{ml}$ aliquot was then taken with a reversed glass pipette, so as to obtain a representative subsample, including any larger aggregates, and transferred to a $20 \mathrm{ml}$ glass vial. Five milliliters of buffered formalin was added (final concentration of $2 \%$ formalin and $0.1 \%$ pyrophosphate buffer) and the samples were stored at $4{ }^{\circ} \mathrm{C}$.

Detachment protocols. The efficiency of the following procedures was tested for detaching bacteria from the 3 substrata preserved in $10 \mathrm{ml}$ buffered formalin:

- an ultrasonic probe (Branson Sonifier 250) connected to a standard resonator and an $11.4 \mathrm{~mm}$ tip (standard flat tip) and operated at an actual output of $80 \mathrm{~W}$ (76 $\mu \mathrm{m}$ amplitude; setting 5);

- an ultrasonic bath (Ney Ultrasonic 300), operated at its maximum power output of $95 \mathrm{~W}$;

- an Ultra-Turrax tissue homogenizer (IKA TP18-10; fixed speed of $20000 \mathrm{rpm}[2013 \times$ g] ) fitted with a standard axis (type N-18G);

- a Stomacher 80 laboratory blender (Seward Medical; maximum capacity $80 \mathrm{ml}$ ) set at maximum speed, which corresponds to a motor rotation of $260 \mathrm{rpm}$. 
Samples were treated for varying time periods ranging from 0.5 to $20 \mathrm{~min}$. The total duration and intervals were chosen according to the expected efficacy of each instrument, but the longest duration was at least 5 min. Samples treated with the ultrasonic probe and tissue homogenizer were cooled with ice during treatment to prevent excessive heating. Cooling was not necessary during treatment with the ultrasonic bath or Stomacher. Time series were run for each instrument and substratum to determine the treatment time that yielded the greatest numbers or biovolume of bacterial cells. The maximum yields were then compared between instruments.

Bacterial counts. Numbers of detached bacteria were determined by epifluorescence microscopy after staining with 4',6-diamidino-2-phenylindole (DAPI) following the general protocol of Porter \& Feig (1980), but using DAPI at a concentration of $5 \mathrm{mg} \mathrm{l}^{-1}$ (Schallenberg et al. 1989). After detachment of bacteria from sediment particles, leaf discs and epiphyton, samples were vortexed. Aliquots of 50 or $100 \mu \mathrm{l}$ were taken after $10 \mathrm{~s}$, about $5 \mathrm{~mm}$ below the surface, and placed into a vacuum filtering manifold containing $3 \mathrm{ml}$ of sterile distilled water $(0.2 \mu \mathrm{m}$ filtered and autoclaved). An additional $3 \mathrm{ml}$ of sterile distilled water was added to insure a homogeneous suspension of bacterial cells. Fifty microliters of a $0.1 \mathrm{mg}$ $\mathrm{ml}^{-1}$ DAPI solution was added and the mixture allowed to incubate for $7 \mathrm{~min}$ in the dark (LofererKrößbacher et al. 1999). Samples were then filtered (vacuum at ca. 200 mbar) through black polycarbonate filters (Millipore GTBP, $0.2 \mu \mathrm{m}$ pore size) supported by a backing filter (Millipore HAWP, $0.45 \mu \mathrm{m}$ pore size) and rinsed with sterile distilled water. Polycarbonate filters were removed from the filtering apparatus, mounted on glass slides in lowfluorescence Cargille immersion oil (Type A, Formula 1248) and observed at $1000 \times$ magnification under a Zeiss Axiolab epifluorescence microscope (filter set 02: excitation G 365, beamsplitter FT 395, emission LP 420). Bacterial cells were assigned to 1 of 8 morphotypes (spherical cocci, ovoid cocci, small rods, large rods, vibrios, spirilli/spirochaetes, cells in chains and filaments) and counted in a minimum of 10

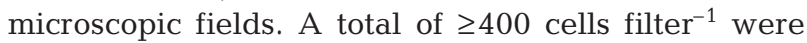
counted (Kirchman 1993).

Biovolumes were calculated assuming that ovoid cells were rotational ellipsoids. All other morphotypes were assumed to be cylinders with hemispherical ends, and biovolumes $(V)$ were calculated using the formula $V=w^{2} / 4 \times(1-w) \times \pi+w^{3} / 6 \times \pi$, where $w$ is the cell width and $l$ is its length. Because of substantial size variability of filaments, the lengths and widths of all encountered filamentous pieces were measured individually using an eyepiece micrometer.
Statistics. The effect of the instruments on the 3 different substrates was analyzed by 2-way ANOVA with instrument and substratum as main factors. Count data were square-root transformed prior to analysis and biovolume data were logarithmically transformed (Sokal \& Rohlf 1995). Extraction efficiencies with different instruments were compared separately for each substratum by 1-way ANOVA, followed by post hoc pairwise comparisons (Tukey's test). Effects were considered significant when $\mathrm{p}<0.05$. All statistical calculations were carried out using SYSTAT.

\section{RESULTS}

Treatment of samples with an ultrasonic probe resulted in an about 5-fold increase of detached bacterial cells from leaf discs compared to simple vortexing (Fig. 1). Ultrasonic treatment for $30 \mathrm{~s}$ was sufficient to yield the maximum number of cells, and prolonged treatment for up to $7 \mathrm{~min}$ did not result in lower numbers. Similar saturation curves were observed when time series were run with the ultrasonic probe, with both sediment and epiphyton samples (Fig. 2): detachment efficiencies from all substrata (leaves, sediment and epiphyton) increased with treatment time and then reached a plateau, regardless of whether bacterial detachment was achieved with an ultrasonic bath or Stomacher (Fig. 2). The Ultra-Turrax treatments also gave similar results except that a $10 \mathrm{~min}$ treatment of epiphyton samples led to a significant reduction of bacterial counts compared to a 1 min treatment $(\mathrm{p}<0.05)$. Thus, in all but one case, prolonged treatment did not result in reduced yields of bacterial cells with any of the 4 instruments tested.

Despite the similar pattern seen in time-course experiments with all instruments, the absolute efficiencies (i.e. the maximum number of cells recovered)

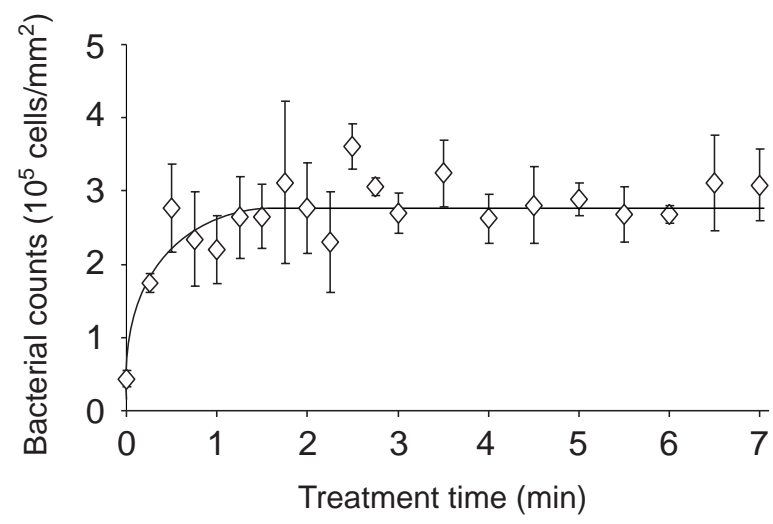

Fig. 1. Time series of detachment of bacterial cells from leaf litter with an ultrasonic probe. Bars indicate \pm SE 


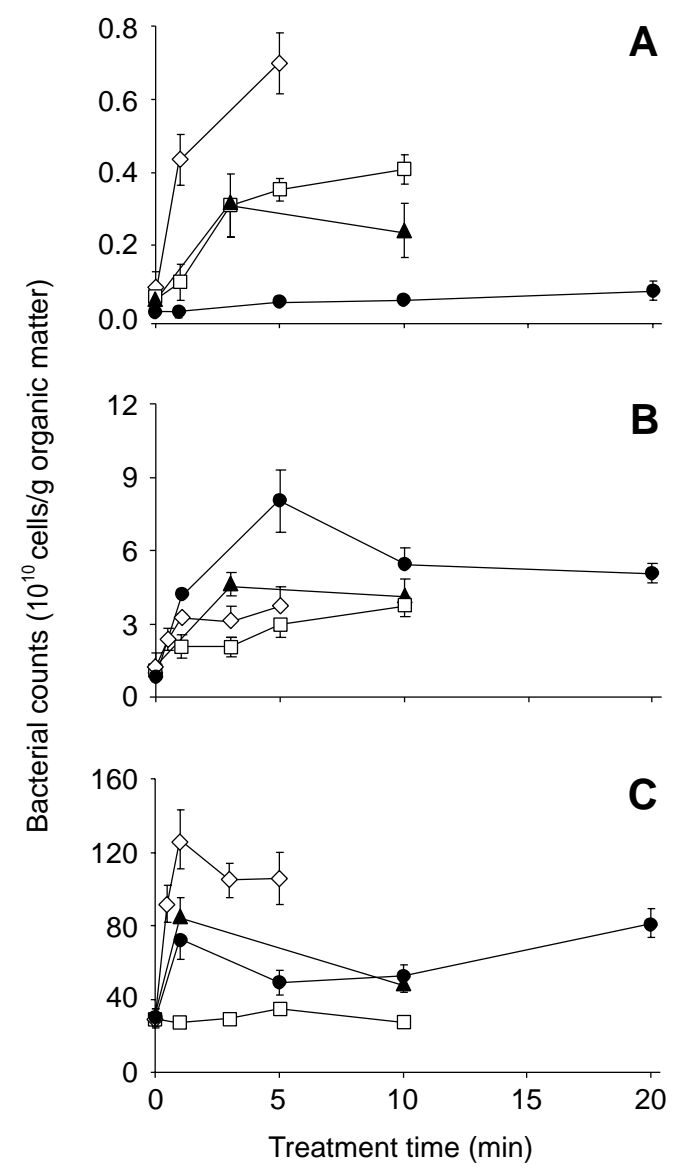

Fig. 2. Time series of bacterial cells detached from (A) leaf litter, (B) sediment and (C) epiphyton with an ultrasonic probe $(\diamond)$, ultrasonic bath $(\square)$, Ultra-Turrax $(\boldsymbol{\Delta})$ and Stomacher $(\bullet)$. Bars indicate $\pm \mathrm{SE}$

differed significantly between instruments (Fig. 2). This effect was observed with all substrata (Table 1). However, the highly significant interaction term between instrument and substratum reveals that the efficiencies of different instruments depended strongly on the substratum examined (2-way ANOVA on square-root transformed count data; $\mathrm{p}<$ 0.001). With leaf litter samples, the Stomacher gave significantly lower bacterial counts than all other instruments (Fig. 2, Table 2), and treatment with the ultrasonic bath and Ultra-Turrax also resulted in significantly lower values than the ultrasonic probe treatment. This outcome contrasts with the results seen with sediments, where the highest number of bacteria was found following treatment with the Stomacher; this higher yield was significant compared to all other treatments (Table 2). Cells associated with epiphytic biofilms were most efficiently re- covered with the ultrasonic probe, as had been found for the bacteria attached to leaf litter. However, with epiphyton, the ultrasonic bath treatment rather than the Stomacher resulted in the lowest yield. Thus, for leaf litter and epiphyton, the ultrasonic probe was most efficient in detaching bacteria from their substratum, whereas for sediment the Stomacher appeared to be the best instrument.

When data were analyzed in terms of biovolume instead of cell numbers, similar patterns emerged (Fig. 3). There was no clear evidence of reduced yields with increasing treatment times, and similar relative differences between instruments were apparent.

The 4 detachment procedures tested here did not generally affect the proportions of different bacterial morphotypes (with one exception), nor did the treatment time influence the apparent morphotype composition of the communities (Fig. 4). However, the relative contributions of morphotypes greatly depend on whether cell abundance or biovolume is considered. Although cocci and rods were the predominant cell forms on all 3 substrata in terms of numbers $(85 \%$ on average), the biovolume of coccal cells was negligible even on sediments, where they made up almost $60 \%$ of the total cell abundance. In addition to rods $(60 \%$ on average), filaments and chain-forming bacteria assumed great importance in terms of biovolume $(20 \%$ and $40 \%$, respectively).

The average biovolume of bacterial cells in epiphytic biofilms ranged from 0.05 to $0.30 \mu^{3}$ with a mean of $0.15 \mathrm{\mu m}^{3}$ (data not shown). Corresponding values for sediment samples were similar with 0.05 to $0.27 \mu^{3}$ (mean of $0.12 \mu^{3}$ ), whereas on leaf litter the average size was slightly greater (range of 0.07 to $0.42{\mu \mathrm{m}^{3}}^{3}$ with a mean value of $0.13 \mu^{3}$ ), due to the larger proportion of filamentous forms.

Table 1. Separate 1-way ANOVAs testing the effects of detachment devices (source of variation) on the abundance and biovolume of bacteria attached to 3 different substrata

\begin{tabular}{|llrccc}
\hline Test parameter & Substratum & df & MS & F-ratio & p-value \\
\hline Abundance $^{\mathrm{a}}$ & Leaf litter & 3 & $2.21 \times 10^{6}$ & 27.9 & $<0.001$ \\
& Error & 12 & $7.9 \times 10^{4}$ & & \\
& Sediment & 3 & $6.33 \times 10^{6}$ & 7.3 & $<0.01$ \\
& Error & 11 & $8.6 \times 10^{5}$ & & \\
& Epiphyton & 3 & $2.00 \times 10^{8}$ & 21.0 & $<0.001$ \\
& Error & 12 & $9.5 \times 10^{6}$ & & \\
Biovolume $^{\mathrm{b}}$ & Leaf litter & 3 & 0.79 & 42.3 & $<0.001$ \\
& Error & 12 & 0.02 & & \\
& Sediment & 3 & 0.25 & 5.0 & $<0.05$ \\
& Error & 11 & 0.05 & & \\
& Epiphyton & 3 & 0.20 & 23.5 & $<0.001$ \\
& Error & 12 & 0.01 & & \\
\hline
\end{tabular}

${ }^{\mathrm{a}}$ Square-root transformed values; ${ }^{\mathrm{b}} \mathrm{ln}$-transformed values 
Table 2. Pairwise comparisons of the detachment efficiency of ultrasonic probe (USP), ultrasonic bath (USB), Ultra-Turrax (UT) and Stomacher (ST) after 1-way ANOVAs of bacterial counts on 3 types of substrata. Signs behind p-values indicate significantly higher $(+)$ or lower $(-)$ efficiency of instruments listed in columns versus instruments listed in rows. ns: not significant

\begin{tabular}{|c|c|c|c|c|}
\hline \multirow{2}{*}{$\frac{\text { Substratum }}{\text { Leaf litter }}$} & & \multicolumn{3}{|c|}{ Comparison } \\
\hline & & USB & USP & UT \\
\hline & USP & $<0.05(+)$ & & \\
\hline & UT & ns & $<0.05(-)$ & \\
\hline & $\mathrm{ST}$ & $<0.001(-)$ & $<0.001(-)$ & $<0.001(-)$ \\
\hline \multirow[t]{4}{*}{ Sediment } & & USB & USP & UT \\
\hline & USP & ns & & \\
\hline & UT & $\mathrm{ns}$ & $\mathrm{ns}$ & \\
\hline & $\mathrm{ST}$ & $<0.01(+)$ & $<0.05(+)$ & $<0.05(+)$ \\
\hline \multirow[t]{4}{*}{ Epiphyton } & & USB & USP & UT \\
\hline & USP & $<0.001(+)$ & & \\
\hline & UT & $<0.01(+)$ & $<0.01(-)$ & \\
\hline & ST & $<0.01(+)$ & $<0.05(-)$ & ns \\
\hline
\end{tabular}

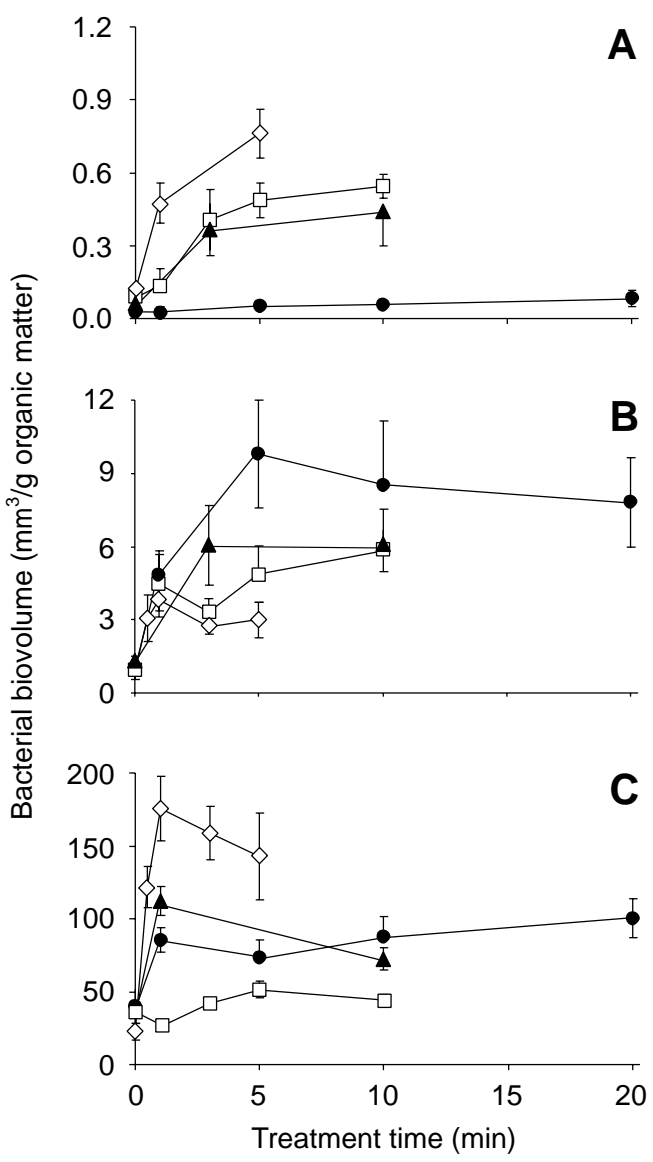

Fig. 3. Time series of detachment of bacterial biovolumes from (A) leaf litter, (B) sediment and (C) epiphyton with an ultrasonic probe, ultrasonic bath, Ultra-Turrax and Stomacher. See Fig. 2 for symbols. Bars indicate \pm SE

\section{DISCUSSION}

The results of this study show that the type of substratum to which bacteria are attached critically affects the relative efficiency of instruments used for extracting bacteria from environmental samples. Most strikingly, the Stomacher laboratory blender produced the highest yields of all 4 instruments tested when used with sediment samples, but gave especially poor results with leaf litter. The performance of the Stomacher with sediments has apparently not been tested in previous studies. However, its high efficiency at extracting bacteria from sediment in the present study is consistent with observations made on soils (van Elsas \& Smalla 1997). This suggests that the Stomacher works well with mineral sample matrices in general, where friction between grains adds to the overall abrasive effect. The same principle would apply to other types of detachment devices. However, with the other instruments, extraction conditions may become so harsh as to result in significant cell disruption and thus diminished cell counts compared to a Stomacher treatment.

Interactions between substratum quality and instrument type could also account for the striking outperformance of the Stomacher by more powerful instruments, particularly the ultrasonic probe, when bacteria are dislodged from leaf litter. This finding seems to be at variance with results obtained by Donegan et al. (1991), who recommend the Stomacher explicitly for detaching bacteria from leaf surfaces. However, the phylloplane bacteria studied by Donegan et al. (1991) may be much less intimately associated with their substratum than the bacteria colonizing decomposing leaves, as in the present study, thus requiring less harsh conditions for efficient detachment. In line with this idea, the harsher extraction procedures achieved with an ultrasonic probe have repeatedly been found most appropriate in the majority of studies comparing instruments for bacterial detachment from organic substrata (e.g. Shelley \& Perry 2000, Mermillod-Blondin et al. 2001), and this was also observed in our experiments with both decomposing reed leaves and epiphytic biofilms.

Part of the conflicting results between studies might be reconciled when apparently minor differences in procedures are taken into account. An important detail to consider is the power actually delivered to the sample (Epstein \& Rossèl 1995). This is especially true for ultrasonic treatments. The power acting on the sample must be high enough to achieve near-complete detachment of cells from their matrix, but below the level where notable cell disruption occurs. The power is influenced by the type and settings of the instrument, the size of the energy-transducing device (e.g. 

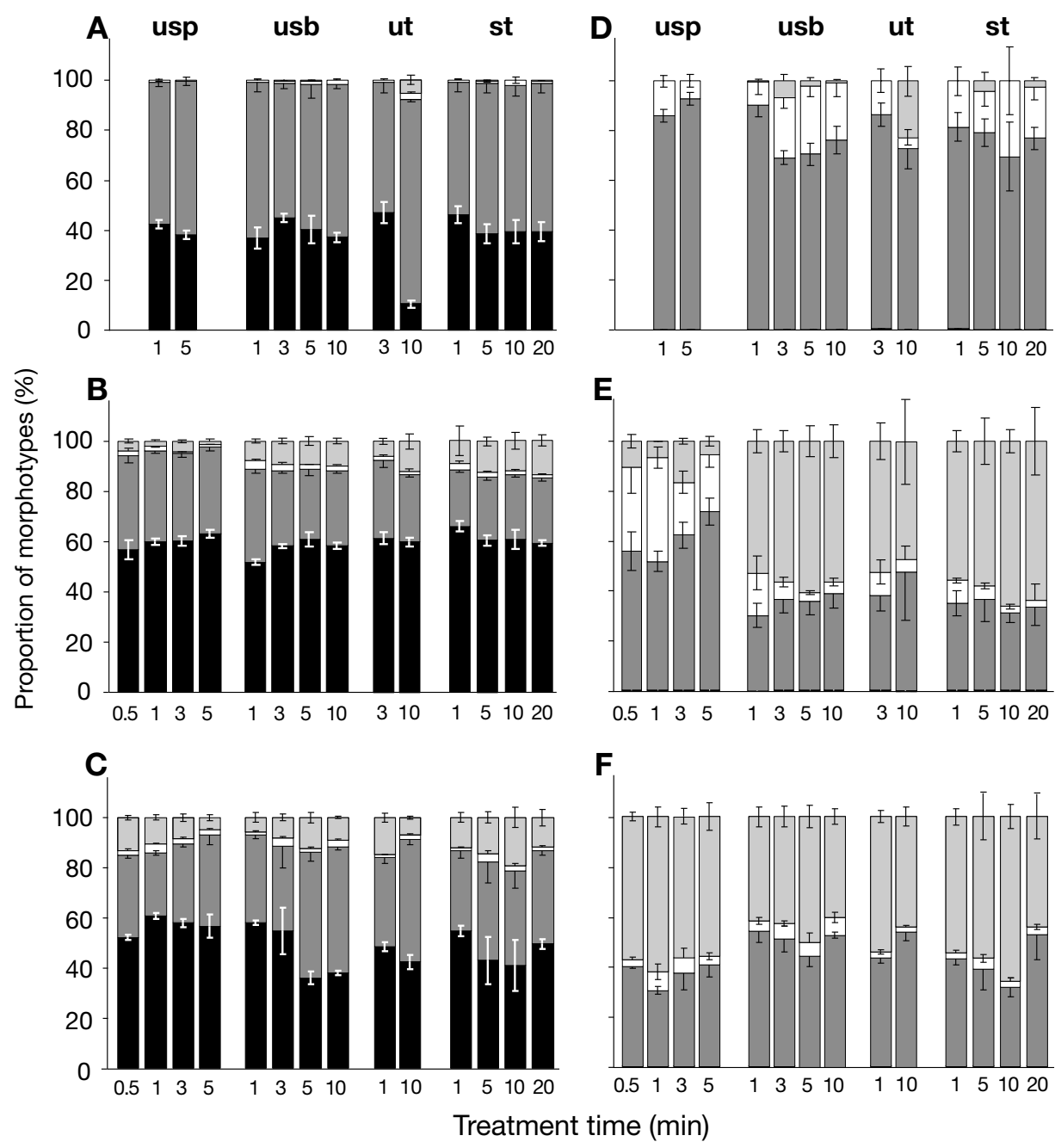

- cocci $\square$ rods $\square$ filaments $\square$ others

Fig. 4. Proportion of bacterial morphotypes in (A, D) leaf litter, $(B, E)$ sediment and $(C, F)$ epiphyton samples. Panels on the left show cell counts and those on the right biovolumes. Instruments used for detachment: ultrasonic probe (usp), ultrasonic bath (usb), Ultra-Turrax (ut) and Stomacher (st). Bars indicate \pm SE

tip diameter of ultrasonic probes) and the proximity of the sample to the power source (Epstein \& Rossèl 1995, Mermillod-Blondin et al. 2001). Sample volume has an effect on the last factor. In previous studies, ultrasonic probes were connected to microtips (3 to $5 \mathrm{~mm}$ diameter; e.g. Ellery \& Schleyer 1984, Epstein \& Rossèl 1995), whereas in the present study a tip with a diameter of $11.4 \mathrm{~mm}$ was used, corresponding to a 5 to 14 times larger area of the blunt tip end. Inserting the broad tip into a $20 \mathrm{ml}$ scintillation vial insured close contact between the power source and suspended particles with attached bacteria, conceivably resulting in a more even distribution of the vibration energy in the sample slurry. The power output of our set-up (80 W, $76 \mu \mathrm{m}$ amplitude, broad tip, $20 \mathrm{ml}$ sample volume, cooling with ice) was about the maximum that could be applied without running the risk of losing sample volume as a result of foaming, and it kept the temperature below $40^{\circ} \mathrm{C}$ during a 1 min treatment (data not shown).

The constant cell counts and biovolumes observed in time-series experiments indicate that cell disruption was largely prevented during prolonged treatment in the present study. This observation is at variance with most studies using ultrasonic probes with microtips (Ellery \& Schleyer 1984, Velji \& Albright 1986, Epstein \& Rossèl 1995; but see Kuwae \& Hosokawa 1999), suggesting that the conditions created by microtips could be too harsh. The alternative hypothesis that overall extraction was inefficient in the present exper- 
iments seems unlikely given that the power output $(80 \mathrm{~W})$ was close to the optimal output $(90 \mathrm{~W})$ found by Shelley \& Perry (2000). In addition, bacterial numbers and average cell sizes, and thus biovolumes, were well in the range of published values (Schallenberg \& Kalff 1993, Fischer et al. 1996, Thomaz \& Esteves 1997, Kuwae \& Hosokawa 1999, Griebler et al. 2001).

In a comparison of 3 instruments used for separating bacteria from decomposing leaves, Maamri (2000) reported a divergence in bacterial counts between instruments of as much as 3 orders of magnitude. In comparison, the greatest differences in the present study were less than a factor of 10, 4 and 2 for leaf litter, epiphyton and sediment samples, respectively. This much narrower range suggests that, apart from the Stomacher treatment applied to decaying leaves, all of the methods tested here yield similar estimates. Consequently, in systems where bacterial abundance varies across several orders of magnitude, (e.g. Baldy et al. 1995), all detachment devices should produce useful results in spite of the statistically significant differences in performance found here.

In addition to information on bacterial numbers, knowledge about the biomass of bacteria is important for understanding the role of these organisms in natural environments. Biomass is commonly derived from biovolume estimates. Therefore, bacterial cell size and shape must be considered in addition to numbers when evaluating instruments and procedures for detaching bacteria from particles and surfaces. Similarly, in analyses of bacterial community structure, it is essential to avoid systematic biases by preferentially extracting some sorts of bacteria but not others. Although the distinction of morphotypes as used in the present study allows a quite limited resolution pattern of the bacterial community structure, the remarkably stable pattern of morphotype distribution across both instruments and treatment times suggests that preferential extraction was not a severe problem. Thus, all 4 instruments and procedures examined in this study may well produce comparable results in terms of bacterial community composition.

In conclusion, the instruments and procedures used in this study for detaching bacteria from sediments, leaf litter and epiphytic biofilms gave results that varied within an order of magnitude or less. Therefore, the most efficient device must be chosen carefully for each type of substratum when the success of an investigation depends critically on accurate estimates of absolute numbers or biomass. Relatively harsh extraction procedures with an ultrasonic probe turned out to be most appropriate with organic materials, such as decaying leaves and epiphytic biofilms, whereas a more gentle treatment with a Stomacher laboratory blender was preferable with mineral sediment particles.

\section{LITERATURE CITED}

Baldy V, Gessner MO, Chauvet E (1995) Bacteria, fungi and the breakdown of leaf litter in a large river. Oikos 74 : 93-102

DeLeo PC, Baveye P (1996) Enumeration and biomass estimation of bacteria in aquifer microcosm studies by flow cytometry. Appl Environ Microbiol 62:4580-4586

Donegan K, Matyac C, Seidler R, Porteous A (1991) Evaluation of methods for sampling, recovery, and enumeration of bacteria applied to the phylloplane. Appl Environ Microbiol 57:51-56

Ellery WN, Schleyer MH (1984) Comparison of homogenization and ultrasonication as techniques in extracting attached sedimentary bacteria. Mar Ecol Prog Ser 15: $247-250$

Epstein SE, Rossèl J (1995) Enumeration of sandy sediment bacteria: search for optimal protocol. Mar Ecol Prog Ser 117:289-298

Fischer H, Pusch M, Schwoerbel J (1996) Spatial distribution and respiration of bacteria in stream-bed sediments. Arch Hydrobiol 137:281-300

Fischer UR, Velimirov B (2000) Comparative study of the abundance of various bacterial morphotypes in an eutrophic freshwater environment determined by AODC and TEM. J Microbiol Methods 39:213-224

Frischer ME, Danforth JM, Newton Healy MA, Saunders FM (2000) Whole cell versus total RNA extraction for analysis of microbial community structure with 16S rRNA-targeted oligonucleotide probes in salt marsh sediments. Appl Environ Microbiol 66:3037-3043

Fry JC (1988) Determination of biomass. In: Austin B (ed) Methods in aquatic bacteriology. JohnWiley \& Sons Inc, New York, p 27-72

Griebler C, Mindl B, Slezak D (2001). Combining DAPI and SYBR Green II for the enumeration of total bacterial numbers in aquatic sediments. Int Rev Hydrobiol 86:453-465

Holben WE (1997) Isolation and purification of bacterial community DNA from environmental samples. In: Hurst CJ, Knudsen G, McInerney M, Stetzenbach LD, Walter M (eds) Manual of environmental microbiology. ASM Press, Washington, DC, p 431-436

Kepner RL, Pratt JR (1994) Use of fluorochromes for a direct enumeration of total bacteria in environmental samples: past and present. Microbiol Rev 58:603-615

Kirchman DL (1993) Statistical analysis of direct counts of microbial abundance. In: Kemp PF, Sherr BF, Sherr EB, Cole JJ (eds) Handbook of methods in aquatic microbial ecology. Lewis Publishing, Boca Raton, p 117-119

Kuwae T, Hosokawa Y (1999) Determination of abundance and biovolume of bacteria in sediments by dual staining with 4', 6-diamidino-2-phenylindole and acridine orange: relationship to dispersion treatment and sediment characteristics. Appl Environ Microbiol 65:3407-3412

Lawrence JR, Korber DR, Wolfaardt GM, Caldwell DE (1997) Analytical imaging and microscopy techniques. In: Hurst CJ, Knudsen G, McInerney M, Stetzenbach LD, Walter M (eds) Manual of environmental microbiology. ASM Press, Washington, DC, p 29-51

Lebaron P, Parthuisot N, Catala P (1998) Comparison of blue nucleic acid dyes for flow cytometric enumeration of bacteria in aquatic systems. Appl Environ Microbiol 64: $1725-1730$

Lemarchand K, Parthuisot N, Catala P, Lebaron P (2001) Comparative assessment of epifluorescence microscopy, flow cytometry and solid-phase cytometry used in the enumeration of specific bacteria in water. Aquat Microb 
Ecol 25:301-309

Loferer-Krößbacher M, Witzel KP, Psenner R (1999) DNA content of aquatic bacteria measured by densitometric image analysis. Arch Hydrobiol Spec Issues Adv Limnol 54: 185-198

Maamri A (2000) A critical comparison of techniques for estimating bacterial abundance on leaf litter decaying in Oued Zegzel (Morocco). Ann Limnol 36:235-239

Mermillod-Blondin F, Fauvet G, Chalamet A, Creuzé des Châtelliers M (2001) A comparison of two ultrasonic methods for detaching biofilms from natural substrata. Int Rev Hydrobiol 86:349-360

Meyer-Reil LA, Dawson R, Liebezeit G, Tiedge H (1978) Fluctuations and interactions of bacterial activity in sandy beach sediments and overlying waters. Mar Biol 48: 161-171

Montagna PA (1982) Sampling design and enumeration statistics for bacteria extracted from marine sediments. Appl Environ Microbiol 43:1366-1372

Porter KG, Feig YS (1980) The use of DAPI for identifying and counting aquatic microflora. Limnol Oceanogr 25:943-948

Schallenberg M, Kalff J (1993) The ecology of sediment bacteria in lakes and comparisons with other aquatic ecosystems. Ecology 74:919-934

Schallenberg M, Kalff J, Rasmussen JB (1989) Solutions to problems in enumerating sediment bacteria by direct counts. Appl Environ Microbiol 55:1214-1219

Servais P, Courties C, Lebaron P, Troussellier M (1999) Coupling bacterial activity measurements with cell sorting by flow cytometry. Microb Ecol 38:180-189

Shelley BCL, Perry JA (2000) Evaluation of bacterial recovery

Editorial responsibility: Gary King,

Walpole, Maine, USA efficiency and counting rrecision from decaying leaf litter in Little Rock Lake, Wisconsin, USA. J Freshw Ecol 15: 157-169

Sokal R, Rohlf FJ (1995) Biometry: the principles and practice of statistics in biological research, 3rd edn. WH Freeman and Co, New York, p 887

Suberkropp K, Klug MJ (1976) Fungi and bacteria associated with leaves during processing in a woodland stream. Ecology 57:707-719

Thomaz SM, Esteves FA (1997) Secondary productivity $\left({ }^{3} \mathrm{H}-\right.$ leucine and ${ }^{3} \mathrm{H}$-thymidine incorporation), abundance and biomass of the epiphytic bacteria attached to detritus of Typha domingensis Pers. in a tropical coastal lagoon. Hydrobiologia 357:17-26

Tso SF, Taghon GL (1997) Enumeration of protozoa and bacteria in muddy sediments. Microb Ecol 33:144-148

van Elsas JD, Smalla K (1997) Methods for sampling soil microbes. In: Hurst CJ, Knudsen G, McInerney M, Stetzenbach LD, Walter $M$ (eds) Manual of environmental microbiology. ASM Press, Washington, DC, p 383-390

Velji MI, Albright LJ (1986) Microscopic enumeration of attached marine bacteria of seawater, marine sediment, fecal matter, and kelp blade samples following pyrophosphate and ultrasound treatments. Can J Microbiol 32: 121-126

Webb PA, Orr C (1997) Analytical methods in fine particle technology. Micromeritics Instrument Corporation, Norcross, p 301

Weyers HS, Suberkropp K (1996) Fungal and bacterial production during the breakdown of yellow poplar leaves in 2 streams. J N Am Benthol Soc 15:408-420

Submitted: July 20, 2001; Accepted: November 20, 2001 Proofs received from author(s): February 8, 2002 